\title{
Fake and Dishonest: Pathologies of Differentiation of the Civil and the Political Sphere in Hungary
}

\author{
Accepted Manuscript Version of the article published in: JOURNAL OF CIVIL \\ SOCIETY 4: pp. 361-374. (2013)
}

\author{
MÁRTON GERÖ* \& ÁKOS KOPPER** \\ *Hungarian Academy of Sciences, Centre for Social Sciences, Institute for Sociology, Budapest, Hungary \\ **Kanagawa University, Yokohama, Japan
}

Correspondence Address: Akos Kopper, Eszék utca 13-15, 1114 Budapest; Email: akoskopper@gmail.com

\begin{abstract}
Almost 25 years has passed since transition, and Hungarian democracy is in a deplorable state. Party politics pervades every aspect of political life, undermining the autonomy of civil actors, treating them as a potential 'fan club' of parties rather than cooperating and consultative partners. In order to capture what went wrong in Hungarian civil society, we propose a structural analysis that highlights pathologies of the differentiation between the political and the civil spheres. We elucidate how the political sphere usurps the autonomy of the civil sphere; thereby not only does it undermine trust in civil actors, but also undercuts their capacity to perform their control function over the political sphere. In the analysis, we concentrate on what we identify as the 'fake-civil/pseudo-civil' phenomenon and related discourses, relying on the conceptual and theoretical apparatus developed by Arato and Cohen.
\end{abstract}

KEY WORDS: Transition, civil society, civil autonomy, structural differentiation, Hungary

\section{Introduction}

If we look back to the time of transition nearly 25 years ago, we find overwhelming optimism concerning the future of Central and East European democracies, which implied that once democratic conditions were established, a gradual evolution of civil activity would ensue and citizens would gradually 'learn to be citizens'. Thus, civil society would evolve converging towards what is typical for West European democracies. The fact that civil organizations (bottom up associational organizations) played a decisive role in the success of transition was considered a promising sign for such an expectation concerning the region, including Hungary, a forerunner of democratization.

Unfortunately, today it seems that these expectations were exaggerated. These days Hungarian democracy has a hard time, and civil society is hardly capable of preventing the dismantling of democratic institutions. In fact, civil society is under political parties' continuous attack, colonizing the civil sphere, usurping its autonomy, and regarding civil agents as a fan club of party politics rather than cooperating partners in democratic life.

Since 2010 Hungary has been run by Fidesz, a party with a two-thirds majority, introducing reforms that are heavily criticized both domestically and internationally for breaching norms of democratic conduct. The country is under sharp criticism from the European Union (EU) and its member states. Viviane Reding, Commissioner for justice, citizenship and fundamental rights, has suggested that the EU should consider suspending Hungary's voting rights under Article 7 of the EU Treaty (see Eurotopics, 2013). Non- 
governmental organizations, such as Freedom House, are also concerned about democracy in Hungary:

Hungary's precipitous descent is the most glaring example among the newer European Union (EU) members. Its deterioration over the past five years has affected institutions that form the bedrock of democratically accountable systems, including independent courts and media. Hungary's negative trajectory predated the current government of Prime Minister Viktor Orbán, but his drive to concentrate power over the past two years has forcefully propelled the trend. (Walker \& HabdankKołaczkowska, 2012, p. 1)

Although the Freedom House report still qualifies Hungary as a consolidated democracy, over the past few years their scores have worsened in all the factors (Walker \& Habdank-Kołaczkowska, 2012, p. 1). Varga and Freyberg-Inan (2012) argue that a 'selective democracy' is in the making in Hungary. By selective democracy they mean that the governing party tries to restrict the legitimate participation of their political rivals or minority groups in the democratic process. Although we agree with their interpretation, we supplement their argument and suggest that selective democracy also includes restricting civil organizations' and social movements' ability to contribute to the political process. This takes place by the colonization of the civil sphere, undermining civil agents' capacity to contribute to the democratic process, curtailing them in acting as one autonomous entity in the vitally important system of checks and balances in a modern democracy. ${ }^{1}$ We elucidate how this process of colonization takes place by focusing on how political parties create 'fake' and 'pseudo-civil' organizations that try to buttress their legitimacy by usurping the resources of the civil sphere. The political parties' attempt to exploit the civil sphere for their own objectives and to see it as no more than a potential 'fan club' supporting party politics leads to crowding out genuine civil agents and undermining trust in civil activity. Our work is inspired by the ideas of Arato and Cohen (Cohen \& Arato, 1992), who emphasize that democratization is preconditioned on the complex relation of civil and political society. We contend that one of the decisive problems of Hungarian democracy is rooted in the distorted differentiation between the political and the civil spheres, with the latter lacking its autonomy.

We operationalize our study by looking at both how political parties - primarily Fidesz ${ }^{2}$ - exploit the civil sphere for party purposes and how the political discourse in the two main Hungarian dailies, Népszabadság and Magyar Nemzet reflect upon this, discussing the pseudo-civil or fake-grassroots phenomenon. It is reasonable to turn to these publications because the media plays a key role in informing citizens about civil agents (Arató \& Nizák 2012, p. 7). By studying media discourse, we capture: (1) the prevailing suspicion that there are no autonomous civil agents, as they are all just puppets of political parties; and in reaction to this, we see in these papers (2) a demand for a black-and-white rigid separation between civil and political society. This has the corollary that, on the one hand, civil actors are regarded as a 'pasttime', a hobby, or in the best case, as charity institutions without any influence on politics, while on the other hand, in case a civil agent or association stands up and has its voice heard in the political process, it is immediately suspected to be a political party's 'cover agent,' no more than a pseudo-civil associate.

Our study has two objectives. First, we intend to contribute to the debate on the pathetic conditions of Hungarian democracy and civil society. Second, we also hope to contribute to normatively inclined theoretical discussions concerning interactions between civil and political society (e.g. Cohen \& Arato, 1992; Foley \& Edwards, 1996; Held, 2006; Hoffmann, 2011; Pierson, 1984). In our structural analysis, we underline that a democratic 
system is to operate with civil and political society interacting in such a manner that the autonomy of the civil sphere is adequately maintained. While boundary-making between the two spheres is part of any democracy - and the terrain of contestation - we suggest that in Hungary discursive boundary-making takes place in a distorted way. ${ }^{3}$

\section{Transition Optimism}

At the time of transition, it was expected that in Hungary - as well as in the whole of Eastern Europe - civil society would converge towards what is typical for West European democracies. The fact that quasi-civil and civil organizations (bottom-up associational organizations) played a decisive role in the success of transition was considered a very promising sign for the evolution of civil society. As Mary Kaldor (2003, p. 586) points out: 'I was deeply involved in the East European discussions and always thought it was they who reinvented the term [civil society]', although she admits that later she learnt that the term 'civil society' had been rediscovered in Latin America earlier.

There is no clear consensus on the conditions of civil society in Central Eastern Europe. Ekiert and Foa (2011) argue that states with a pre-war experience of a nascent civil society and with independent movements contributing to the success of transition had the tradition of self-organization, which after transition alleviated the formation of civil societies. They identify a significant gap between two groups of states in respect of the strength of civil society: the post-socialist countries of Central Europe, which have a well developing democratic system and the post-Soviet countries, where authoritarian regimes were rebuilt. Other authors who use Western societies as a point of comparison conclude that civil society is quite weak in Hungary, mostly in terms of participation (Wallace, Pichler, \& Haerpfer, 2012). Gerő examined trends of participation (membership, volunteering, and involvement in unconventional forms of participation), finding that although there was growth in the 1990s, there is stagnation and even a decline from 2000 to 2010 (Gerő, 2012).

Perhaps expectations for a strong civil sphere to come to the fore were somewhat unwarranted. Dahrendorf (1990) and Szabó (2009) point out that as social learning may take decades or even generations, we should not be surprised that the East European civil sphere has not matured yet. Others were skeptical because they argued that after transition the civil sphere would actually lose its significance (Seligman, 1992). Ost (2011) points out that although civil movements played an important role in the transition, most of those civil groups were transformed into political parties, or their leaders became part of the elite either in the field of politics or in administration, as a result of which they were no longer interested in mobilizing society. Concomitantly, would-be civil society was left without politically active and experienced leaders. Also, the fact that many of the civil agents in Eastern Europe were 'top-down' in character and were externally funded rather than membership-driven (Wallace et al., 2012, p. 5) could have been taken as a warning sign that the future of a prosperous and vibrant civil society was far from assured.

Two main difficulties in judging the state of civil society are ambiguities concerning the actors considered 'civil' and the operationalization of such notions as trust in civil society. Thus, for example, when Arató and Nizak (2012) infer 'trust' about civil society by asking Hungarian citizens who they turn to in order to have their problems solved and find that citizens trust municipalities and local authorities more than civil agents, they measure an instrumental and practical aspect of 'trust' that says little about whether citizens regard civil agents as honest and autonomous rather than corrupt and self-serving. 
Sometimes it is extremely difficult to decide whether an actual agent qualifies as civil or not and therefore should be included in the data. Thus, for example the 'Peace March' (Békemenet in Hungarian) claims to be a civil agent regularly organizing rallies and marches in support of the ruling Fidesz government. If we consider the Peace March as a civil agent, we might conclude that there is an energetic civil sphere in Hungary, mobilizing tens of thousands of citizens. However, the intimate connections between Fidesz and the organization raise serious doubts as to whether the Peace March qualifies as a civil agent. While this may be regarded as a problem of qualification, we believe that there is more to it. In fact, it is by elucidating this problem of the relationship between civil and political agents that we can uncover what we believe to be one of the core problems for the maturation of civil society in Hungary today. One illuminating question that Arató and Nizák asked citizens in their research was how they explained their reservations in case they were skeptical about civil agents. They have found that by far the most important reason why citizens doubt civil agents is that they consider them mere affiliates of parties. Over 54 per cent of respondents answered that they have doubts concerning civil agents because they are proxies manipulated by political parties (Arató \& Nizák, 2012, p.16).

Putting this differently, on the surface Hungary in many ways seems to have a well operating democratic life, with Békemenet representing the civil sphere or rounds of so-called national consultations conducted regularly and seeking citizens' opinion. Yet observed more closely, it is questionable whether Békemenet and many other organizations are indeed civil, while national consultations arguably serve more the interests of government propaganda than seeking citizens' opinion. However, highlighting that agents are not what they claim to be being proxies or co-opted agents of political parties - or showing that institutions do not serve their purported purposes should be only the first step of an analysis. We believe in order to capture the core of the problem we need to engage in a structural analysis. In the next section, we offer a framework to show why an adequate differentiation between the civil and political societies is indispensable for a democratic society to function, while subsequently we will use this framework to pinpoint pathologies of the Hungarian civil sphere.

\section{Differentiation and Interaction between the Civil and Political Societies}

The relationship between democracy and civil society is subject to debate. On the one hand, classical theories of civil society argue that the vitality of civil society is the pre-requisite for a strong democracy (Edwards, 2009; Putnam, Leonardi, \& Nanetti, 1993; Tocqueville, 2006). On the other hand, some believe that with adequate institutions in place citizens would learn to be civil. Stable democratic institutions in place provide the backdrop for civil society to evolve (Letki \& Evans, 2005). In spite of the debate whether civil agents or institutions should come first, there seems to be an agreement on the fact that a stable democracy presupposes both a strong civil society and a strong political sphere. Held (2006, p. 275) argues that democratization is - in his terms - a double-sided process, by which he means that the state and civil society must acquire their autonomy, because it is only if these two spheres correct each other's malfunctions that democratic life can flourish. Elucidation of this mutual interdependence between the state and civil society calls for a systematic approach that scrutinizes the complex interconnectedness of civil and political society, such as the one offered by Cohen and Arato in their seminal book, Civil Society and Political Theory (1992).

In the model proposed by Arato and Cohen, society is divided between the system, which consists of formal interactions of politics and economic activity, and the lifeworld, where private interactions between citizens take place. Relations between these two parts of 
social activity are conducted through what they identify as civil society and political society. Both of these are associational organizations with the function of mediating between the system and the lifeworld. It is essential for the argument of Arato and Cohen that although both civil society and political society are associational, they are constituted in a fundamentally different way. While political society is based on formalized forms of association such as suffrage (with its dominant actors being political parties), civil society is rooted in the free and informal associations of citizens (Arató, 1999; Arato \& Cohen, 1999). It is important to point out, however, that although civil society is submerged to the lifeworld and political society is tied to the system, the former is different from the fully informal institutions of the lifeworld, while the latter differs from the institutions of governance and of the state.

These spheres are differentiated but are also integrated through different integration mechanisms. Thinking along ideal types, political actors are driven by the need to be 'efficient'. Their aim is to prevail over competing political agents. This implies that they 'cannot afford to subordinate strategic and instrumental criteria to the patterns of normative integration and open-ended communication characteristic of civic society' (Cohen \& Arato, 1992, p. vii). Agents of civil society, however, are more prone to realize communicative action, which 'involves a linguistically mediated, inter-subjective process through which actors establish their interpersonal relations, question and reinterpret norms, and coordinate their interaction by negotiating definitions of the situation and coming to an agreement' (Cohen \& Arato, 1992, p. 435).

The difference in the operational logic of the political and the civil sphere is also related to the fact that whereas civil actors tend to be single-purpose entities, political actors are not. Civil actors usually - although not necessarily - have a well-defined single objective: protecting the environment, promoting the neighbourhood, struggling for animal rights. Political actors, however, even if they have a well-defined value orientation, are frequently forced to balance between contradictory objectives. Whereas political parties must take a position on all problems of social life and integrate them into a coherent world-view, civil actors may single-mindedly stand for protecting animal rights, traditional values or the establishment of colonies on Mars.

The differentiation of the two spheres does not mean that civil society has no role to play in politics; its role is primarily to control and influence. In a somewhat idealized narrative, civil society provides the terrain for unconstrained discussion of issues in a manner where norms tend to prevail over interests. Thus, the system and the lifeworld supplement one another; thereby they create the resources both in the material and social terms that modern mass societies require. Whereas the former caters for social co-ordination and administration, the latter caters for the linguistic-cultural resources required by social integration and reproduction.

Cohen and Arato argue that the democratic quality of a political life in any society is dependent on the relations and communications between the two spheres. ${ }^{4}$ They need to be adequately distinct, yet they need to cooperate: 'The mediating role of political society between civil society and state is indispensable, but so is the rootedness of political society in civil society' (Cohen \& Arato, 1992, p. x). Although political society in many ways originates in civil society's associations, political society creates the legal and institutional setting for the activities of civil society. Figure 1 captures visually that the political and civil sphere show some overlap. 
By overlap, we mean that in their interactions the political and the civil spheres must remain autonomous and follow their own operational logic, while at the same time, they should also be at least 'partially conversant in the language of the other sphere'. Fonyó, Kollár and Sükösd (2007) showed, for example, in case of Green organizations how the discourses of different actors might converge. Environmental NGOs and political actors tend to have a 'multi-lingual character', knowing how to speak both the language of the civil society and of political society. Putting this differently, civil society should be autonomous, nevertheless it must also be able to 'talk politics' and interact with political actors. By their involvement, civil actors are supposed to tame the way political actors operate, instill the logic of the lifeworld into the political process - among others, provide the normative underpinnings of political life, which can be formally institutionalized by obligatory processes of social dialog or establishing an office for the ombudsman. It is the adequate interaction of the two spheres that enables the self-correcting mechanisms of democracy to operate efficiently (Miszlivetz, 2010).

The bottom line of Arato and Cohen's argument is that democratization is preconditioned on a complex interaction between civil and political society, where the two influence one another, yet remain distinct; in other words, they need to cooperate but need to be properly differentiated at the same time (Cohen \& Arato, 1992). ${ }^{5}$

\section{Pathology of Differentiation: The Fake Civil Phenomenon}

By using the above framework, we identify pathologies of differentiation between Hungarian civil and political society. We will show first how the system colonizes lifeworld - i.e. how political actors usurp the resources of the civil sphere to buttress their legitimacy. Second, we will argue that the reaction to this is a call for a radical differentiation between the two spheres, leading to a divergence from the ideal suggested by Arato and Cohen both on the level of practices (inadequate differentiation) and also on the level of normative expectations as reflected in the discourse (call for excessive differentiation). Clearly, practices and normative expectations are not independent, but feed into one another. Thus, the process is not linear and does not take place in clearly distinguishable stages. Rather, it is a circular and self-reinforcing process where political discourse reflects on actual political practices, and political discourse, in turn, is reflected in political practices. Talking about colonization, we do not only mean political actors' strategies used to exploit the resources of the lifeworld, but we also refer to the destruction it creates in expectations and trust concerning the civil sphere.

It should also be underlined that based on this model, the border between civil society and the state is never fixed but is the subject of political contestation. ${ }^{6}$ In any democracy, the political sphere (as much as the economic) makes attempts to usurp the resources of the civil sphere to buttress its legitimacy. There is a level beyond which, however, such practices undermine the autonomy of the civil sphere, and help maintain the image that civil agents are but proxies of political actors. A way political agents can borrow 'trust' in civil agents is by creating formally independent organizations that, in reality, are closely affiliated with a political party. Mcnutt and Boland (2007) refer to this phenomenon as 'astroturfing', meaning that mock grassroots organizations are established to manipulate the debate over political or economic issues. The impression that there is genuine grassroots support for a cause can be a powerful means to steer decision-making.

Thus, relying on civil agents, political actors can greatly enhance their legitimacy. The general phenomenon that trust in civil organizations tends to be higher than in political parties makes this strategy possible. Surprisingly, despite low participation rates, this relatively high 
trust in civil society is true for Hungary and Central and Eastern Europe in general (Marinova, 2011; Péterfi, 2010, 2013). One explanation could be that citizens in Central Eastern Europe see their state as corrupt and unreliable; therefore they treat actors outside of the state as relatively trustworthy (Marinova, 2011). Hence, once civil organizations become generally suspected to be tied up with political parties, or to have a hidden agenda, citizens naturally lose their trust in them, as Márkus (2009) has demonstrated for Hungary. This being said, occasionally there is but a fine line between 'clever' grassroots constituency making and 'dishonest' acts to shape public policy via mock agents. By looking at what we identify as the issue of pseudo or fake-civil associations, we mean political practices and subsequently discourses about political actors' attempts to create civil society associations that are civil on the surface, but in fact are intimately tied to the political sphere.

The starting date for our analysis is the summer of 2002. It was after the electoral defeat of Fidesz that the party invested enormous energies into calling to life an extensive network of so-called 'civil circles' (polgári körök) of locally rooted groups of sympathizers. Although these groups were closely tied to Fidesz, the name suggests that they were somewhat independent, outside the party framework. In Hungarian, the name is just as ambiguous as in English. That is, by referring to civil circles, Fidesz already aimed to exploit the multiple connotations of the term 'civil'.

A similar process of buttressing the party via the creation of civic organizations also took place in case of MSZP, the socialist party. Before the 2006 elections, Ferenc Gyurcsány, the incumbent socialist Prime Minister at the time, initiated the creation of a new 'independent' organization, the Foundation for the Modern Left (Amöba). Amöba started as an online game played by groups, nevertheless it was important that members or players were to meet not only online, but also in person, offline. ${ }^{8}$ The idea was to foster the creation of independent groups with leftist value orientations. Gyurcsány was actively involved in the foundation - he was a regular guest at Amöba's events, which no wonder raised doubts concerning the independence and autonomy of the organization. ${ }^{9}$

In both cases, political actors' instrumental calculations are obvious. Once the Socialists won the general elections in 2006, they lost interest in Amöba; the foundation was facing increasing financial problems and eventually ceased operations altogether, which indicates that it had no genuine grassroots basis. The fate of Amöba, however, is not unlike that of the civil circles, which are almost totally forgotten by now, or more precisely, have been replaced by the Civil Union Forum (CÖF), an umbrella organization founded in 2009 (Bolgár, 2013).

In 2011, the Civil Union Forum became the background organization to the Committee for Civil Cooperation and a year later to the Peace March (Békemenet) - the sort of Fidesz 'fan club' mentioned previously - organizing regular protests and marches in order to 'protect' the government and express their sympathy for the party ruling with a two-thirds majority. Such marches are rather absurd, invoking the memory of marches in favour of the pre-transition Communist Party, indicating a move towards a corporatist model of civil society, where the expected role of civil agents is restricted to legitimizing and supporting the government. ${ }^{10}$ The underlying vision of the relationship between state and civil society is clearly reflected by how the leader of the Civil Union Forum, Tamás Fricz, defined it, identifying the nation with the state, the government and civil society, as if they were one indivisible entity: 'The Hungarian government and the Hungarian state will only be able to defend the national sovereignty if a sovereign and independent civil society stands behind them, which not even the forces of Hell will defeat' (Fricz, 2013).

In this case, talking about independence is absurd if the term is understood as the independence of civil society from the state and political parties. Yet, arguably what Fricz is 
referring to as independence is the nation's sovereignty from 'foreign' interest, a trope that came to the fore in the discourse on fake-civil agents as an established method for undermining the legitimacy of civil agents critical of Fidesz politics. ${ }^{11}$

The fact that political astroturfing has become an established political strategy is indicated by the advice the well-known political scientist András Giró-Szász offered in 2008 to a prominent local Fidesz politician. He suggested that Fidesz should closely monitor what civil organizations their political opponent may launch and book their probable domain name well in advance (hvg.hu, 2010). Similarly, a draft version of the MSZP strategy has recently been leaked. The document says the party should establish 'a civil or advocacy organization or union, which will ensure the socialist party to cooperate with the party during the upcoming elections' (Baloldaliság, remény, erő- adalékok az MSZP stratégiájához, 2012, p. 16). These sets of advice are not only instructive of the kind of strategies parties employ, but they also prove that creating fake-civil organizations has become political actors' established practice.

The natural reaction to these practices is a mounting skepticism concerning the authenticity and autonomy of civil agents, as political actors and the media try to uncover their fake-civil nature. In order to capture this skepticism and unveiling process, we looked at how this issue came to the fore in the two main daily newspapers of Hungary, Népszabadság and Magyar Nemzet, the former being associated with the left, whereas the latter with the political right. We focused on articles in which the authenticity of agents of civil society had been challenged. What we were interested in was not merely statements and claims in which civil agents were denounced for not being authentic, but were also interested in the general normative attitude, the 'frame' through which civil society and its relation to the political sphere were interpreted. By looking at the two main daily newspapers, we wanted to grasp the normative and conceptual framework projected in respect of the pseudo-civil issue. By looking at the adjectives, slogans and value judgments used in the context of the pseudo-civil discourse, we had the aim to distil the interpretative frame that evolved concerning the relationship between the political and the civil spheres. We were interested in the depiction of both the actual and the idealized relationship between the political and the civil spheres.

In the comparison of the two dailies, we have found that the left-leaning Népszabadság has a more tamed-down rhetoric, which in our opinion is merely due to a difference in writing style. In general, the pseudo-civil topic was almost as prevalent in Népszabadság as in the right-leaning Magyar Nemzet. We were not surprised to find Népszabadság to be more critical and attentive of identifying right-leaning fake- and co-opted organizations. In the context of the pseudo-civil discourse, we believe the following comments speak for themselves, because they not only identify associations as fake, but also give the more general context of denouncement. Thus, in Népszabadság we found the following idiomatic expressions: 'wearing a civil makeup', being 'closely tied to a party', being 'a leftover from the times of the one-party system', being 'power-hungry', 'selfserving', being a 'career civilian', being 'state-created', 'standing for others', being an 'auxiliary association/troop', and 'promoting party politics while hiding behind a pseudo-civil organization'. 12

In the right-leaning Magyar Nemzet the nature of the discourse is similar, but typically presented in a rougher style. In this vein, Magyar Nemzet tends to name concrete actors, while Népszabadság speaks in more general terms. Also Magyar Nemzet interprets events by invoking conspiracy theories, and the fake-civil topic lends itself to such framing. Here some of the characteristic expressions we found were 'interest-led left', 'fake-left-wing', 'pro-forma civil', 'using a loaded dice', 'fake-liberal'. What is characteristic of the discourse is the denunciation of actors by challenging their autonomy and completely disregarding what they 
actually claimed to be standing for. Labels like 'fake-liberal', 'fake-pluralist', 'interest-led left-winger', and 'fake-conservative' all suggest that the person is not what s/he claims to be.

Our study of the two main Hungarian dailies has shown that talking about 'fake-civil' agents has become an established trope of political discourse and the labelling of actors as puppets of competing political entrepreneurs has developed into a recurrent political strategy both on the political left and on the political right. The corollary of the fake-civil trope gaining ground is that civil actors feel an increasing need to argue for - and to demonstrate - their independence. The following statement by civil organizations is a pertinent example of civil actors trying to preserve their credibility and their fight against being crowded out by party affiliates:

We, the undersigned real civil associations would like to bring to the citizens' attention that they should watch critically these - not truly 'civilized' - public actors who lack the civil virtue to confess that they intend to serve party interests in a civil costume. (Szücs, 2010)

Besides statements like this, civil organizations constantly try to avoid any contact with politicians, the expression of which has taken various forms: statements to make sure that they keep a distance from members joining a political party, or explicitly asking politicians and political organizations not to join their demonstrations. ${ }^{13}$

What is the outcome of such a framing of the discourse about the civil sphere? In general, increasing suspicion prevails and civil actors are looked upon with doubt. Civil agents are naturally suspected of having a hidden agenda and serving their political masters. Such a depiction of actual practices has the corollary to bring to the fore on the normative level a call for an ideal world, where there is a firm distinction between the civil and the political spheres. The outcome of the call for a full separation of the two spheres leads to the possibility of undermining any civil agent's credibility, since the nature of their work fosters contact among them. The discourse of pseudo-civils and the uncovering of connections among the civil and political organizations create the feeling that there are no real or independent civils, but only puppets of parties. This feeling is confirmed by Arato and Nizak (2012), showing that the majority of Hungarians do not trust civil organizations because they believe that they hide political parties.

Although Cohen and Arato's model emphasizes the complex inter-relationship between the two spheres, in this image being a civil actor is somewhat synonymous with being engaged in a sort of part-time, recreational type of activity without any relevant political implications. ${ }^{14}$ If such ideas prevail, they lead to a distorted image concerning the role of civil actors in a democracy, as they have the perverted effect of raising suspicion about civil actors, who in fact, perform roles of advocacy, criticize governmental policies and raise public awareness. Although these are civil agents' essential activities and are crucial in providing a democratic control of political life, as a result of the prevailing discourse, it is exactly these kinds of civil activities that are looked upon with suspicion. ${ }^{15}$

Recapitulating what Arato and Cohen mean by the vital connection among the two is the capacity of the civil sphere to influence the political sphere, while at the same time remaining autonomous. It is under such conditions that the civil sphere can steer the discursive habits of political society by instilling its communicative logic into it. What we witness in Hungary is the exact opposite of such an interrelationship. The political sphere colonizes civil society and crowds out its communicative argumentation even from places where communicative argumentation should naturally prevail. Concomitantly, the civil sphere is less and less capable of acting as a 'watchdog' of the political process. We should underline 
again that the point is not that agents of the political sphere are 'bad' and civil agents are 'good'. Instead, the point Cohen and Arato make is that they operate according to a different logic and it is the balance of the two which is necessary for the well-functioning of a democracy.

\section{Conclusion}

Our article aimed to offer a structural analysis to capture the problem with civil society in Hungary. We have shown that Fidesz embarked on creating a 'selective democracy' not only by attempting to restrict its political rivals' participation in political life, but also by colonizing civil society.

When ten years ago Fidesz was preoccupied with creating civil circles, one could have the impression that they had a vision of politics where politics is predominantly built up from local associations, with civil society playing a considerable role in providing inputs for the political process. By contrast, what we see today is the exact opposite of such a vision of politics. On the one hand, Fidesz had been inviting citizens to the so-called national consultations, sending out millions of letters directly to citizens, in a way suggesting that there is no need for the mediating role of civil associations as the state can directly talk to the citizenry. Naturally, such an exchange of letters between individuals and the state totally lacks debate, opinion formation and consultative capacities, the typical qualities of the civil sphere. On the other hand, there is the Peace March (Békemenet), a movement in support of Fidesz, reminiscent of the Socialist parades supporting the party in power. However, with such agents as the Peace March claiming to be representatives of civil society, it is no surprise that Arato and Nizák had found that citizens' main problem with civil agents is that they doubt their independence and autonomy, suspecting them of being proxies of political parties (Arató and Nizák 2012, p. 16). Thus, agents who claim to be civil are either immediately suspect of being pseudo-civil associates of a political party or are regarded as a 'pasttime', a hobby or, at best, as charity institutions without any influence on politics. A pertinent example capturing this general mood is a Socialist politician's statement claiming that 'politics is for professional politicians and citizens should stick to their "civil-ish" things' (Csillag, 2008). The implication is that civil society has nothing to do with the serious work politicians are engaged in.

We have argued that on the one hand, the prevailing practice of creating fake-civil organizations and on the other hand, the perception that civil society is just a leisure time activity are both symptoms that the differentiation between the political and civil spheres is pathological. This questions the honesty of the democratic operation of Hungarian society and creates a fake system that is free and open only in the narrow procedural sense. If the political sphere colonizes the civil sphere and thereby the lifeworld, the democratic operation of society is undermined, even if otherwise democratic institutions remain in place.

\section{References}

Arató, A. (1999) Civil Társadalom Lengyelországban és Magyarországon [Civil society in Poland and Hungary], In A. Örkény (Ed.), Civil társadalom, forradalom és alkotmány [Civil Society, Revolution and Constitution] pp. 53-81 (Budapest: Új Mandátum). 
Arato, A., \& Cohen, J. L. (1999) Civil society and the public sphere. In A. Örkény (Ed.), Civil társadalom, forradalom és alkotmány [Civil Society, Revolution and Constitution], pp. 118-146 (Budapest: Új Mandátum).

Arató, K., \& Nizák, P.(2012) Az érdekérvényesítéssel foglalkozó civil szervezetek társadalmi beágyazódottsága Magyarországon [Embededdness of Advocacy Civil Organizations in Hungary], Civil Szemle 2012(2) pp. 5-23.

Baloldaliság, remény, erő- adalékok az MSZP stratégiájához. [Leftism hope and encouragement - addendum for the strategy of Socialist Party] (2012) Available at http://www.pecsma.hu/wp-content/uploads/2012/10/106074761-Baloldalisag-

Remeny-Ero.pdf, (accessed 05 June 2013).

Bolgár, Gy. (2013) A polgári körök helyébe lépett CÖF-röl. [About CÖF replacing civil circles] Interview with Tamás Fricz. Klub Radio, 13. February 2013. Typed version is available at Galamus.hu http://galamus.hu/index.php?option=com_content\&view=article \&id=191182\&catid=6 9\&Itemid=106\&limitstart=1 (Last accessed 06.05.2013).

Cohen, J. L., \& Arato, A. (1992) Civil Society and Political Theory (Cambridge: MIT Press).

CÖF (2013) Open Letter to Jose Manuel Barroso (in Hugarian) Civilosszefogas.hu Available at http://www.civilosszefogas.hu/component/content/article/1-friss/419-nyilt-level-azeuropai-parlamentnek.html. (accessed 05 June 2013).

Csillag, G. (2008) Civilek és profik, [Civils and Professionals], Népszabadság, 02 January 2008 Available at http://nol.hu/archivum/archiv-476464. (accessed 05 June 2013)

Dahrendorf, R. (1990) Reflections on the Revolution in Europe: In a Letter Intended to Have Been Sent to a Gentleman in Warsaw (London: Chatto \& Windus).

Edwards, M. (2009) Civil Society (Cambridge: Polity Press).

Egymillióan (2011) Kedves mindenki! [Dear All], http://egymillioan.blog.hu/2011/04/12/osszefogas_15 (accessed: 10. June 2013).

Ekiert, G., \& Foa, R. (2011) Mítosztól a valóságig: civil társadalom Közép- és KeletEurópában, [From Myth to Reality: Civil Society in Central and Eastern Europe], Civil Szemle, 2011(1-2), pp. 90-118.

Eurotopics (2013) EU threatens Hungary with sanctions. Eurotopics. 2013.04.18. Available at http://www.eurotopics.net/en/home/presseschau/archiv/archiv_dossier/DOSSIER1218 18-EU-threatens-Hungary-with-sanctions (accessed: 04 June 2013).

Facebook (2011) A Hallgatói Hálózat elhatárolódik Polgár Dórától. [The Student Network distances itself from Dóra Polgár], Statement of the Student Network. Available at: http://www.facebook.com/note.php?note_id=302591729754592 (last accessed: 2013. 06.05).

Foley, M. W., \& Edwards, B. (1996) The paradox of civil society. Journal of Democracy, 7(3), pp. 38-52.

Fonyó, A., Kollár, E., \& Sükösd, M. (2007) Discursive strategies in GM policy: A theoretical assessment. In B. Clements (Ed.), Probing the Boundaries of Environmental Justice and Global Citizenship, pp. 169-183 (Oxford: Inter-Disciplinary Press).

Fricz (2013) The speech of Tamás Fritz at the celebration of Hungarian and Polish Civil organizations (in Hungarian) Available at

http://www.youtube.com/watch?feature=player_embedded\&v=Gz4ZzI-hyJU\#! (accessed: 2013. 06-05).

Gerő, M. (2012) A civil társadalom néhány trendje Magyarországon 1990 után, [Trends of Civil Society in Hungary after 1990], In I. Kovách, C. Dupcsik, T. P. Tóth \& J. Takács (Eds.), Társadalmi integráció a jelenkori Magyarországon, [Social Integration in 
Hungary], pp. 317-342 (Budapest: Argumentum-MTA Társadalomtudományi Kutatóközpont Szociológiai Intézet).

Held, D. (2006) Models of Democracy (3rd ed.) (Cambridge: Polity Press).

Hoffmann, J. (2011) In the Triangle of Civil Society, Politics, and Economy: Positioning Magazines of Nonprofit Organizations. Voluntas: International Journal of Voluntary \& Nonprofit Organizations, 22(1), pp. 93-111.

hvg.hu. (2010) Gerillaakciókhoz vezethez a médiakontroll, [Controlling the Media may Leads to Guerilla Acts], Hvg.hu. 2010.11.30

Kaldor, M. (2003) The Idea of Global Civil Society, International Affairs, 79(3), pp. 583-593.

Letki, N., \& Evans, G. (2005) Endogenizing social trust: Democratization in East-Central Europe. British Journal of Political Science, 35, pp. 515-529.

Marinova, D. M. (2011) When government fails us: trust in post-socialist civil organizations, Democratization, 18 (1), pp. 160-183.

Márkus, E. (2009) Civilek a sajtóban - Közmegítélés, [Public Opinion - CSOs in the Press], Civil Szemle 5(1-2), pp. 156-168.

Mcnutt, J., \& Boland, K. (2007). Astroturf, technology and the future of community mobilization: implications for nonprofit theory. Journal of Sociology and Social Welfare, XXXIV(3) pp. 165-178.

Miszlivetz, F. (2010) 1989 újraértelmezése, [Re-evaluating 1989], Magyar Tudomány (október), pp. 1215-1226.

Ost, D. (2011) The decline of civil society after post communism. In U. Liebert \& H.-J. Trenz (Eds.), The New Politics of European Civil Society, pp. 163-177.: New York Routledge).

Perez-Diaz, V. (1998) The public sphere and a European civil society. In J. C. Alexander (Ed.), Real Civil Societies, pp. 211-237 (London: Sage).

Péterfi, F. (2010) Példátlanul alacsony a közbizalom - Gyorsjelentés 2009. [Public Trust is Unprecedentedly Law - Flash Report 2009] (Budapest: Közösségfejlesztők Egyesülete).

Péterfi, F. (2013) Közbizalom 2012, [Public Trust - 2012], Közösségfejlesztés

Pierson, C. (1984) New theories of state and civil society. Recent developments in postMarxist analysis of the state, Sociology, 18(4), pp. 563-571.

Putnam, R. D., Leonardi, R., \& Nanetti, R. Y. (1993) Making Democracy Work (Princeton, New Jersey: Princeton University Press).

Stratégiai partnerségi megállapodás (2011) Stratégiai partnerségi megállapodás. (Strategic partnership agreement) Kormany.hu. Available at http://www.kormany.hu/download/d/b9/60000/KIM_Civil_Osszefogas_Kozhasznu_A lapitvany.pdf (accessed 05 June 2013).

Szabó, M. (2009) Autonómia és etatizmus a magyar civil társadalomban, [Autonomy and Etatism in Hungarian Civil Society], Politikatudományi Szemle, 3, pp. 157-163.

Szücs, K. (2010) CIVIL A PÁLYÁN. Több civil szervezet képviselője és magánember tiltakozása a politikai képviseletre törekvő álcivil szervezetek ellen, [Representatives of Civil Organizations Protest against Pseudo-Civil Organizations' Aim for Political Representation]. halas.hu available at: http://drupal.halas.hu/content/civilp\%C3\%A1ly\%C3\%A1n-t\%C3\%B6bb-civil-szervezet-k\%C3\%A9pvisel\%C5\%91je\%C3\%A9s-mag\%C3\%A1nember-tiltakoz\%C3\%A1sa-politikai-k\%C3\%A9pviselet (accessed: 16. May 2013).

Tocqueville, A. d. (2006) Political Associations in the United States (H. Reeve, Trans.) Democracy in America (Vol. 1) (Project Gutenberg). 
Varga, M., \& Freyberg-Inan, A. (2012) The threat of selective democracy. Popular dissatisfaction and exclusionary strategy of elites in East Central and Southeastern Europe, Southeastern Europe, 36(3), pp. 349-372.

Walker, C., \& Habdank-Kołaczkowska, S. (2012) Fragile Frontier: Democracy's Growing Vulnerability in Central and Southeastern Europe Nations in Transit 2012 (Freedom House), $\quad$ http://www.freedomhouse.org/sites/default/files/Release\%20Booklet.pdf (accessed 16 May 2013.)

Wallace, C., Pichler, F., \& Haerpfer, C. (2012) Changing patterns of civil society in Europe and America 1995-2005: Is Eastern Europe different? East European Politics \& Societies, 26(1), pp. 3-19.

\footnotetext{
${ }^{1}$ At the same time, it is important to stress that despite curtailing the legitimacy of the former in taking part in politics, the opposition sitting in parliament legitimates the political game; what takes place can be read as a shift towards a two-pole electoral system with two main political blocks, where Fidesz's aim is not to exclude the left from the political game, because it actually needs it for the legitimization of its power. The aim is merely to assure that the left does not become strong enough to challenge the rule of Fidesz. As long as this is assured, a two-party system where Fidesz is to win is the ideal Fidesz scenario.

${ }^{2}$ Actually, Fidesz is in coalition with the Christian Democrats, but in reality, the Christian Democrats are a facade, hardly existing as an autonomous political entity.

${ }^{3}$ What do we mean by civil society? While generalist approaches identify it with social order in general (PerezDiaz, 1998), for minimalist approaches it is just one sphere of society. Our understanding is closer to the latter interpretation, although the important point for us is to realize that modern societies are comprised of different subsystems, with each operating according to its distinct logics. What we focus on are pathologies of these differentiations, undermining the democratic life of societies.

${ }^{4}$ Although the economic sphere is also an integral part of the framework, we put this issue aside, while we acknowledge that there are fake-civic organizations that specifically strive to receive funds intended for supporting the civic sphere.

${ }^{5}$ It is justifiable to ask what could actually be read as an indicator that the ideal Arato and Cohen call for is approximated. Such indicators can be: there are various forms of extensive consultations inviting civil agents to join decision-making processes; party politics not pervading all aspects of social life; occasional bipartisan decisions, where party interests are trumped by the common good; de-centralized decision-making procedures etc. It is also important that politics is able to govern, make decisions and successfully implement them, sometimes with the help of civil organizations.

${ }^{6}$ The distinction between what counts as civil and what counts as political is therefore not always straightforward but is permeated with ambiguities. Drawing the line, making this distinction is anything but trivial. This shows that differentiation between political and civil is not a question of a pre-given definition but is part and parcel of the self-constitution and reflexive operation of the socio-political system. It is a constant and never-ending boundary-making process between the political and the civil. For a community to operate democratically, it is necessary to be able to establish this distinction in a way to define norms of political conduct where the two spheres remain autonomous and at the same maintain their ability to cooperate.

${ }^{7}$ Actually, Fidesz had earlier exploited this ambiguity when adding the words Polgári Szövetség to its name. By this move it tried to ally (szövetség=alliance) itself with citoyens or burghers (the meaning of the Hungarian polgár). This had the corollary that the previously neutral polgár suddenly acquired party-political connotations.

Again paradoxically, these groups were ambiguously defined as neither political nor civic entities. The founding document of the organization lays down ' $[t]$ he aim of the foundation is to preserve the values of civil society, to promote tradition and political culture...' (quoted from the founding document of the organization, available at the court).

${ }^{9}$ Their 'fake grassroots' characteristics were obvious - at least from the outside - and they were made even worse when party leaders actively promoted them. Thus, for example, when the Prime Minister appeared at a 'civic tent' proclaimed as a stage for civic discussion, the phoniness of the event was evident. Claims by the Prime Minister that he was there 'merely' in his civic capacity only exacerbated the event's fakeness.

${ }^{10}$ In 2011, the CÖF also became the government's official strategic partner (Stratégiai partnerségi megállapodás, 2011),
} 
${ }^{11}$ As an example, see the letter of the Civil Union Forum to Jose Manuel Barroso: 'It is possible that a Peace March from Hungary to Brussels will be necessary, where we invite and request the solidarity of all nations and well-meaning communities who share our vision of a Europe made up of fully equal nations guarding their national sovereignty.' (CÖF, 2013)

${ }_{12}$ We tried our best to render our findings despite limitations of language and the difficulty of accurate translations for frequently figurative expressions.

${ }^{13}$ As an example, see: A Hallgatói Hálózat elhatárolódik Polgár Dórától. [The Student Network distances itself from Dóra Polgár], (Facebook 2011), Kedves mindenki! [Dear All] (Egymillióan 2011).

${ }^{14}$ This obviously does not mean that there are no organizations recognized as genuinely civil. Nevertheless, there is a general aura of suspicion and distrust.

${ }^{15}$ This issue also has an aspect concerned with the problem of funding and financing civic organizations. However, this topic is outside the scope of the present paper, although doubts about the financial independence of civic agents certainly aggravates the problem of 'fakeness'. 